Lengthy urinary tract decompression is best obtained by cutaneous ureterostomy . When a temporary diversion is required, loop ureterostomies are performed; each ureter is exposed through a small incision in the flank, a loop is exteriorised and the ureteral wall incised to allow urinary drainage (Johnston, I963). When permanent diversion is the object, the ureters are divided close to the bladder and brought to the surface; it is often possible to site both stomata in the midline so that a single collecting appliance can be used.

\title{
REFERENCES
}

Harlowe, S. E., Merrill, R. S., Lee, E. M., Turman, A. E. \& Trapp, J. D. (1965). F. Urol. 93, $4 \mathrm{II}$.

Johnston, J. H. (1963). Archs. Dis. Childh. 38, г6г.

Johnston, J. H. (1966). F. Pediat. Surg. I, 583.

Jones, E. R. V. \& Williams, J. E. (1967). Devl. Med. Child Neur. Suppl. 13, I 3.

Kirkiand, I. (1962). Devl. Med. Child Neur. 4, 3 I4.

NASH, D. F. E. (1957). Ann. Roy. Coll. Surg. Eng. 20, 349.

Nash, D. F. E. (I968). Hosp. Med. 2, 439.

RoBerTs, J. B. M. (I96I). Br. F. Urol. 33, 309.

Roberts, J. B. M. (1962). Ann. Roy. Coll. Surg. Eng. 31, 69.

SMART, P. J. G. (I965). Br. F. Urol. 37, 574.

Smith, E. D. (1965). Spina Bifida and The Total Care of Spinal Meningomyelocele. Springfield, Illinois : Thomas.

Rose, R. S. \& SMITH, J. P. (I963). F. Urol. 90, I29.

Ross, J. C., Gibbon, N. O. K. \& Damanski, M. (I958). Br. F. Urol. 30, 204.

ZaChary, R. B. \& Sharrard, W. J. W. (1967). Post-grad.med. F. 43, (Suppl. to Nov. 1967).

\section{PRINCIPLES OF MANAGEMENT OF THE COMPLICATIONS OF THE NEUROGENIC BLADDER}

\author{
By R. M. JAMESON, F.R.C.S. \\ Liverpool Regional Urological Centre, and Regional Paraplegic Centre, Southport
}

IT is well known that the commonest causes of death in the paralysed patient with the neurogenic bladder are urinary infection and renal failure (Hutch and Bunts, I95I). Urinary tract infection plays an important role in the development of the complications associated with the neurogenic bladder.

There are several factors which influence bacterial growth in urine (Table I); for example it is not usuallyappreciated that the urine of normal individualscontains sufficient glucose and amino acids for bacterial growth (Asscher, 1968). Normal urine contains 50 to $80 \mathrm{mg}$./1. of glucose which, although it is not detected by routine ward tests, is ample for maximal growth. Even if the food supply is adequate, products of cell metabolism can accumulate and prevent further growth and this can be recorded as an alternation of the $\mathrm{pH}$ of the culture medium or urine. Bacterial growth is inhibited at a pH of less than 5 and more than 8 (Roberts I968) (Table II). In practice it is easier to maintain the urinary $\mathrm{pH}$ on the acid side of the mean normal of $\mathrm{pH} 6$ (normal range of urinary $\mathrm{pH}_{4} \cdot 8$ to $7 \cdot 4$ ). Although it is traditional to prescribe potassium citrate to make the urine alkaline it is difficult to make the $\mathrm{pH}$ high enough to inhibit bacterial growth for more than brief periods; moreover, phosphates will be precipitated from an alkaline urine. B. proteus and 
Ps. pyocyaneus can break down urea and raise the urinary $\mathrm{pH}$ and if the bladder mucosa is damaged an alkaline phosphatic cystitis may result (Hager, 1926; Jameson, 1966, 1967).

\section{TABLE I}

Factors influencing Bacterial Growth in Urine

I. Body temperature.

2. Urine contains sufficient glucose $(60 \mathrm{mg} . / 1$.$) and amino acids for$ maximum growth rate.

3. Urinary $\mathrm{pH}$ ideal but growth inhibited by $\mathrm{pH}$ less than 5 or more than 8.

4. Renewal of culture medium by urine production.

5. Residual urine ensures some bacteria still present in bladder.

6. Organisms present in urethra and perineal skin can invade bladder via urethra.

7. Some organism (B. proteus and Ps. pyocyaneus) can split urea to obtain cell energy. These organisms make the urine more alkaline.

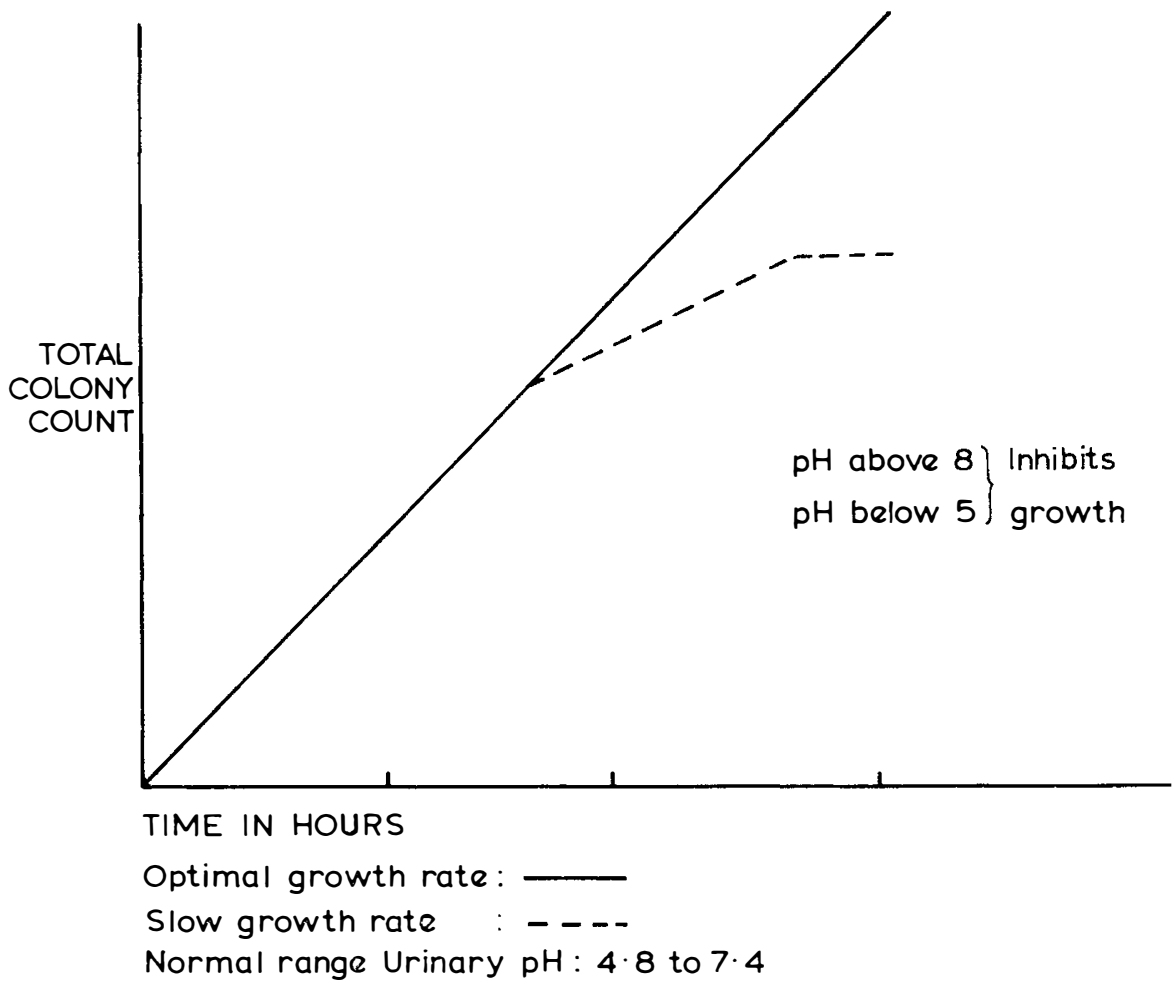

Conditions in a patient with a urinary infection differ from the Petri dish in the laboratory; an in vitro analogy would be the continuous flow system of a culture medium as is used in the manufacture of the penicillins, as in man the infected bladder urine is being continually replenished by the urinary output. O'Grady (I966) studied the kinetics of urinary tract infection using an experimental model and found that by frequent voiding infection could be eliminated from the bladder unless a large residual urine was present. Using a computer as a second experimental 
model he found that if $E$. coli multiplied at the maximum rate in a bladder with hourly voiding the organisms could be removed if the residual urine was less than $70 \mathrm{ml}$. If the residual urine was high and voiding infrequent, the organisms could never be removed from the bladder. O'Grady emphasised that although it was mathematically possible to remove all organisms from the bladder by frequent voiding, provided that the residual urinewas low, that patients need sleep and, during the night hours when the bladder was not emptied, bacterial growth would continue so that the organism count within the bladder could be very high the next morning. In I92 I David introduced $E$. coli into the bladders of normal dogs and found that they disappeared after a few hours. If a residual urine was present cystitis and renal infection developed. He also noted that if the dogs had sores, similar organisms were isolated from the urine and sores. In the male the distal urethra contains pathogens (Helmholz, I950), and similar organisms can be found in the female (Guze and Beeson, 1956). Moore has emphasised the role of the female urethra as a source of infection and Kass showed that pyelonephritis develops in some women with a bacilluria of pregnancy. Renal factors which may be related to infection are the high ammonia level in the medulla which inhibits complement and protoplasts which can grow in the medulla (Guze, I964).

Urinary Infection and the Complications of the Neurogenic Bladder. Consideration of the factors which influence the development of the complications associated with the neurogenic bladder show that urinary tract infection is vitally important (Table III).

\section{TABLE III}

Complications of the Neurogenic Bladder in which Infection is a Factor

I. Renal failure with or without hydronephrosis.

2. Vesico-ureteric reflux.

3. Renal and bladder stones.

4. Pressure sores.

5. Amyloid disease.

6. Lower urinary tract infections.

7. Possibly, phlebothrombosis and pulmonary embolus.

Renal Failure and Pyelonephritis. Chronic pyelonephritis is the commonest cause of renal failure in the paraplegic. Damanski and Gibbon (1956) found that one-third of their patients had pyelonephritis and that it could develop as early as eight weeks or as late as eight years after the spinal injury. Although it is usual to find some degree of dilatation of the renal tract, they emphasise that pyelonephritis can occur in the paraplegic without hydronephrosis and record five such cases. Hutch (I957) asked 'Why may a person who sustains a transection of the spinal cord develop hydronephrosis and die of uraemia?' There are three factors which influence development of the hydronephrosis:

I. Nerve damage.

2. Back pressure.

3. Urinary infection.

Hutch (1957) believes that nervous impulses from the distal part of the spinal cord were responsible for bladder contractions, trabeculation and reflux. The 
presence of nerve fibres in the renal pelvis and ureter was uncertain until recently when Notley (1968) found, by electron microscopy, nonmyelinated nerve fibres in the renal pelvis and upper ureter. This neural factor may explain the higher incidence of hydronephrosis and reflux in high cord lesions (Bors and Comarr, I952).

In the paraplegic the problem of pyelonephritis is not in its diagnosis by urine culture, white cell excretion tests, serology and intravenous pyelography, but in the management. Although the results of long-term treatment of chronic pyelonephritis in childhood are encouraging (Stansfeld and Webb, 1954), the results in the paraplegic are disappointing, as any degree of dilatation of the upper urinary tract will prevent more than a transient benefit from antibiotic treatment (Ross, Damanski and Gibbon, 1957). Stamey (1965) stated that with antibiotic therapy the urine will become sterile in 48 to 72 hours after treatment of a urinary tract infection. In patients with a neurogenic bladder other factors must play a part in preventing resolution of infections.

\section{PRINCIPLES OF MANAGEMENT OF URINARY TRACT INFECTIONS}

From a study of the clinical and laboratory evidence four principles may be deduced which guide in the management of the patient with a neurogenic bladder (Table IV).

\section{TABLE IV}

Principles in the Management of Urinary Tract Infections

I. Good urine flow without obstruction.

2. Closed drainage system.

3. General condition of the patient.

4. Effective antibiotic treatment.

The most important is to ensure an unimpeded flow of urine; this is of fundamental importance as antibiotic treatment is of little value if there is an obstruction in the urinary tract.

I. Renal Failure with or without Hydronephrosis. The renal failure found with chronic pyelonephritis is of the non-oliguric type; the kidney cannot concentrate well and tubular damage may result in loss of sodium, potassium and in acidosis. If an obstructive element is present there will be a poor water conservation and sodium loss. Occasionally, patients with chronic renal failure mimic acute obstructive renal failure with a diminution of urinary output, cellular debris and urates blocking the urine drainage system either in the kidney or ureters. If the urine is alkaline and a $B$. proteus or Ps. pyocyaneus infection also present phosphatic stones may develop.

An intake of at least 31 . daily is needed to maintain a good urine flow without risk of dehydration and obstruction from debris. The electrolytes may need adjustment by dietary measures as required. The diet may require adjustment to prevent any excess of protein or vitamin deficiencies. In the acute stage of pyelonephritis, in addition to the above measures, antibiotics and free closed drainage of the urinary tract are needed. Operative removal of the obstruction at 
the bladder neck by resection or division of the external sphincter is employed once the acute infection has settled down (Gibbon, Ross and Damanski, 1965). Urinary diversion to overcome obstruction is less commonly required (Ross, I967).

Whatever régime is employed in catheterisation, a careful technique is important to prevent infection and pyelonephritis. The use of an antiseptic urethral jelly (Chlorhexidene, 'Hibitane') before instrumentation and the supple inert plastic Gibbon catheter of small-calibre draining into a closed plastic container have done much to diminish the risk of urinary tract infection.

2. Vesico-ureteric Reflux. Reflux is often related to urinary infection (Hanley, 1963). The use of measures to improve bladder emptying with a forced diuresis and antibiotics are of value (Ross, 1956). The results of operative surgery upon the incompetent valve are disappointing in the adult neurogenic bladder.

3. Renal and Bladder Stones. Renal stones are known to be related to prolonged immobilisation. Since the introduction of early rehabilitation of the paraplegic and a high fluid intake to promote a forced diuresis the incidence of stone has diminished (Comarr, I955). Stones can form in the bladder around fragments of the balloon catheters or from hair accidentally introduced during catheterisation. The use of better techniques can prevent this risk. Mention has already been made of the risk of an alkaline cystitis and phosphatic deposition in the bladder wall following urinary infection with urea-splitting organisms. Renal stones will have to be removed if they cause obstruction and bladder stones are usually small and soft enough to be dealt with by litholopaxy.

4. Pressure Sores. If an ischaemic area becomes wet and soggy, tissue necrosis can occur, and if this becomes infected tissue damage can spread to surrounding structures such as bone. Sores are a hazard in the paraplegic and indirectly concern the urologist as by good management infected urine can be prevented from dribbling upon a sore. The following case illustrates some of the principles of management.

REPORT. The patient, aged I8 years, had a spina bifida. In childhood he had recurrent urinary tract infections and vesico-ureteric reflux. Dilatation of the upper urinary tract developed and 5 years ago the urine was diverted into an ileal conduit to preserve the renal function. Recurrent infection with $B$. proteus caused encrustation around the stoma which became stenosed and 2 years ago this was refashioned. His renal function improved and the dilatation of the renal pelvis and ureters became less.

The patient gained weight and because of the protuberance of his abdomen, lax abdominal muscles and scoliosis leakage occurred around the ileostomy device. Severe pressure sores developed involving bone and bilateral amputation was performed. Urine continued to leak from his ileostomy and the bladder became infected. To prevent further infection the urine leakage had to be stopped ; this urinary drainage was controlled by insertion of a Foley catheter into the ileostomy and drainage into a closed system. At this time he had a $B$. proteus pyelonephritis which was treated with Ampicillin and cephaloridine. His serum antibodies to $B$. proteus were raised and after the course of treatment they fell.

Infection of the bladder after urinary diversion is rare (Kemp, I966). In the first instance bladder washouts with an antiseptic or antibiotic solution are needed and later a simple cystectomy can be performed. There are only a few reports in the literature (Kemp, I966; Nash, I956) and I get the impression that it occurs mainly in children usually 
girls, rather than in adults. As it is uncommon it is not justifiable to remove the bladder at the time of urinary diversion as this would increase the operativemortality (Wells, I956).

5. Amyloid Disease. Longstanding infection is known to be the most important factor in amyloidosis, which affects the kidney in 83 per cent. of cases of amyloid disease (Auerbach, 1944). Prevention of infective complications by early referral to a Paraplegic Unit where specialised care is given reduces the mortality and morbidity (Damanski and Gibbon, 1956). Once the condition has developed little can be done but progress of the disease can be reduced by good management (De Wardener, I967).

6. Lower Urinary Tract Infections. These complications are due to ascending infection and bad management. Urethritis, peri-urethral abscess and fistula may develop if the catheter is too large and rigid. Such a catheter will not allow drainage of the urethral secretions and may cause pressure necrosis of the urethra or a stricture either at the peno-scrotal junction or just behind the external meatus; the use of an aseptic technique, using an antiseptic urethral jelly and a fine non-irritant Gibbon catheter, will prevent such complications. Inadequate drainage apparatus and a balanitis will allow infection to involve the lower urinary tract. Routine circumcision will prevent a balanitis (Damanski, 1967) and modern techniques using urethral antiseptics, inert small calibre catheters and a close system of urine drainage has made epididymitis less common (Jameson, 1968). When epididymitis occurs it is secondary to inflammation around the verumontanum (Page, 1954; Lyn and Nesbit, 1948). Urethral fistulae can also occur from pressure from a urinal or a hard mattress (Griffiths, 1956). Preventative measures embody the principles previously outlined. These urethral injuries can be repaired surgically.

7. Phlebothrombosis and Pulmonary Embolism. These complications are related to prolonged immobilisation and infection. If lower urinary tract infections with involvement of the pelvic veins can be prevented and early activity of the patient made possible the hazard of pulmonary embolus is reduced.

\section{SUMMARY}

Urinary infections and renal failure threaten the survival of the patient with a neurogenic bladder. The principles of treatment of the neurogenic bladder are stated and the management of complications are reviewed.

\section{ACKNOWLEDGEMENTS}

I acknowledge the encouragement given by my colleagues on the Paraplegic Unit, especially Mr. Cosbie Ross, Dr. Silver and Mr. Gibbon; also the staff of the Pathology Department at Sefton General Hospital, in particular Dr. Jones and Mr. Cox for performing the bacteriological studies.

\section{REFERENCES}

Asscher, A. W. (1968). Communication, National Symposium on Urinary Tract Infection, Royal College of Physicians, London.

Auerbach, O. \& Stemmerman, M. G. (1964). Archs. intern. Med. 74, 244.

Bors, E. \& ComARR, A. E. (1952). F. Urol. 68, 691 . 
Comarr, A. E. (1955). F. Urol. 74, 447.

DAMANSKI, M. (1967). Hosp. Med. 2, 39.

DAMANSKI, M. \& GibBon, N. O. K. (1956), Br. f. Urol. 28, 24.

David, V. C. (I92 I). F. Am. med. Ass. 76, 494.

Gibbon, N. O. K., Ross, J. C. \& Damanski, M. (1965). Int. F. Paraplegia, 2, 264.

GRIFFITH, H. L. (I956). Quoted by Ross, J. C., in Handbook Encyclopedia of Urology, Vol. I2, p. 103.

Guze, L. B. \& Beeson, P. B. (1956). Nerw Engl. Med. F. 255, 474.

Guze, L. B. \& Kalmanson, G. M. (1964). Science, N.Y. 143, I340.

HAGER, B. N. (1926). f. Urol. 16, 447.

HANLEY, H. G. (1963). Lancet, I, 22.

Helmholz, H. F. Snr. (I950). F. Urol. 64, I 58.

Hutch, J. A. (1957). F. Urol. 77, 123.

HutCh, J. A. \& BunTs, R. C. (I95I). F. Urol. 66, 2 I 8.

JAMESON, R. M. (I966). Br. F. Urol. 38, 89.

JAMESON, R. M. (1967). Br. F. clin. Pract. 21, 463.

JAMESON, R. M. (1968). Br. F. Urol. In press.

Kemp, D. R. (I966). Br. F. Surg. 53, 236.

Lyn, J. M. \& NesBit, R. M. (I948). F. Urol. 89, 59 I.

MOORE, T. \& Hira, N. R. (I964). Br. F. Urol. 37, 25.

NASH, (1956). Br. F. Urol. 28, 387.

Notely, R. G. (I968). Br. F. Urol. 40, 37.

O'Grady, F. \& CATTEll, W. R. (I966). Br. F. Urol. 38, I49.

Page, B. H., Miller, A. \& Paine, D. T. H. (I954). Proc. Roy. Soc. Med. 47, 8I I.

Roberts, A. P. (1968). Communication, National Symposium on Urinary Tract Infection. Royal College of Physicians, London.

Ross, J. C. (1965). Br. F. Surg. 52, I64.

Ross, J. C. (1967). Br. F. Urol. 39, 708.

Ross, J. C., DAMANSKI, M. \& GibBon, N. O. K. (I957). Lancet, 2, I 520.

WARDENER, H. E. DE (1967). The Kidney, p. 367. London: Churchill.

WeLLS, C. (1956). Br. F. Urol. 28, 333.

\title{
INTERMITTENT CATHETERISATION IN PARAPLEGIA
}

\author{
By Dr. J. J. WaL SH, M.D.
}

The history of the early treatment of the bladder in paraplegia has been discussed in a number of papers over the years and it is unnecessary to give all the details once again.

As is so often the case with a difficult problem in medicine, a number of different forms of treatment have been advocated and the popularity of each method has waxed and waned at different times and in different places. It is interesting, for example, that suprapubic cystostomy at one time very widely recommended, became outmoded following criticism by Guttmann (I947) and others. Recently an attempt has been made to revive it in a modified form, the vesicostomy recommended by Lapides and other workers (I960) but I feel that this revival will be short-lived. At present indwelling urethral catheter drainage is the most widely practised form of treatment in new lesions.

Having been faithfully married to one particular method of choiceintermittent catheterisation - for nearly 20 years I would like to present my views and experiences with this method.

Intermittent catheterisation has one particular disadvantage; it is demanding and time-consuming, particularly for medical officers, but I am convinced that this 